\title{
Release of Saccharifying Amylase from Lysing Bacterial Cell ${ }^{*}$
}

\author{
by Yosio MiYamoto, Akemi Fukuoka and Shukuko IkaWA**
}

Received July 29, 1966

Many interpretations on how enzymes are released from microbial cell have already been proposed. But despite the importance of the problem, the conclusive theory is very far from being known, and much is done for discussion in connection. with this subject. For example, Nomura ${ }^{1,2)}$ and his colleagues published voluminous papers on the $\alpha$-amylase liberating mechanism in Bacillus subtilis group concluding that the enzyme release is caused by cell autolysis. Pollock ${ }^{3}$, in his profound work, expressed his criticism on Nomura's opinion. Also Yamamoto ${ }^{4)}$ did not align himself with Nomura in this point of view.

One of us, Fukuoka isolated from a starch pool a strain of gram variable rod, actively hydrolysing starch into glucose. As we have observed in this strain distinct autolysis in the course of amylase production, we have intended to see whether lysis of the cell is causative of amylase release or not.

\section{Material and Methods}

Organism and growth conditions: The above mentioned bacterial strain was used throughout. As its full description will be published in another place ${ }^{5}$ very soon, its characteristics are given here briefly. Gram variable, straight rods, 1.1 to 1.3 by 5 to 6 microns, with rounded ends, occurring singly, occasionally in chains especially in an earlier stage of cultivation. Spores, 1.5 to 1.6 by 2.1 to 2.5 microns, always terminal. Motility, weak or absent. Strictly aerobic. Gas production, negative. Temperature relations: optimum, between $30^{\circ}$ and $37^{\circ}$, no growth at $55^{\circ}$, survival limit, ca. $90^{\circ}, 20 \mathrm{~min}$. Hydrolysing starch into glucose. Abundant growth and good saccharifying amylase production in the medium, containing $20 \mathrm{~g}$ soluble starch (JIS special grade, washed with ethanol in Soxhlet's apparatus for $40 \mathrm{hrs}$.) and $5 \mathrm{~g}$ yeast extract powder in 1 litre dist. water, when its initial $\mathrm{pH}$ value is adjusted to 5.0-5.8. The $\mathrm{pH}$ value of this medium finally reaches to 6.8-7.2. Orange yellow, not fluorescent, pigment is produced in this medium. No growth or occasionally very scanty growth occurs either in the ordinary bouillon-peptone broth or on its agar slant, even if it is fortified with carbohydrate, e. g. starch, dextrin, maltose, glucose, etc. Any synthetic medium has not yet been successful. From the features described above and from other biochemical reactions examined, we took this bacterial strain belonging to Genus Bacillus. In “Bergey's Manual, 7th ed., 1957", we count under 25 bacilli 14 amylolytic species. The mentioned strain is different from any of these 14 species in several points, respectively. We are yet prudent in deciding its species name, we call this strain tentatively " $\mathrm{AK}-3$ ".

* Respectfully dedicated to Dr. Shizuo Hattori. Contributions from the Biological Institute, Ehime University No. 123.

** Biological Institute, Ehime University, Matsuyama, Japan. 
Bacteria were always grown at $30^{\circ}$ in $100 \mathrm{~m} l$ medium in $500 \mathrm{~m} l$ Sakaguchi's flask on a shaker, reciprocating at 100 cycles per min. in $10 \mathrm{~cm}$ stroke. The inoculum size was two standard loops (in diameter $3 \mathrm{~mm}$, of platinum wire $0.33 \mathrm{~mm}$ thick) from agar slant of the described medium.

Amylase and lysis: To estimate the amylase activity, the amount of reducing sugar resulted from starch was determined after Somogy's or Lehmann-MaquenneSchoorl's method with some modifications. Starch used here was soluble one, specially prepared for amylase determination by Wako Chemical Industries, Ltd. Osaka, and its 0.56 or $1 \%$ solution was applied. To follow the bacterial lysis the turbidity (in T\%) of the medium was measured at 530 or $660 \mathrm{~m} \mu$ by a photoelectric photometer, Hitachi FPW-4 model. The color tone change of the medium was pursued at 370 $\mathrm{m} \mu$. The ultraviolet absorption was determined by a spectrophotometer, Hitachi EPU-2A.

Electron microscopic preparations: Cell lysis was followed electronmicroscopically also. Cells were, in usual manner, fixed in $6.25 \%$ glutaraldehyde and $1 \%$ osmic acid solution in phosphate buffer of $\mathrm{pH} 7.0$, dehydrated in acetone series, then embedded in Epoxy resin. Ultrathin sections, stained with uranyl acetate, were examined in a Nihon Denshi Type JEM-15 electron microscope.

\section{Results}

Bacterial growth and amylase release.

In the above described conditions, the logarithmic phase starts after long (6-8 hrs.') lag, then the stationary phase begins at $12-13$ hrs.' culture age, and the declining at 17-18 hrs.' age. In every growth phase, at adequate time intervals, aliquots of medium were aseptically pipetted out, and with those samples, the changes of nature of culture medium in the course of growth were pursued. As it can be seen in Fig. 1, the amylase activity (cf. curve C) appears in the medium at the late logarithmic phase of bacterial growth (cf. curve A), increases rapidly, reaches its plateau in the late stationary phase, keeps up the plateau for several hours but declines in the long maintained culture. Namely the amylase activity in the medium follows the bacterial growth with some time lag. Naturally the reducing sugar content (curve B) in the medium shifts nearly along with the amylase activity, but does not decline so much even in the bacterial declining phase.

As the turbidity of the medium increases, it becomes gradually deeper in orange yellow colour, and in the early stationary phase, within one-half or one hour it changes reddish. Such a tone never fades even in the declining phase, but rather deepens (cf. curve D). With the changes of colour of culture, there increases an anomaly in the bacterial population, i. e., ghost cells and anomalies in the cell wall (Fig. 2). These anomalies are observed even in the earliest culture age, also in small colonies of scarcely visible size on the agar plate. But in the later stage of the culture, especially in deep coloured culture, almost all the cells are in the abnormal appearance, suggesting that the majority of them are confronted with lysis.

These cultural features mentioned above, except the medium colour change, correspond to those in the case of Bacillus subtilis after Nomura et al., ${ }^{1,2)}$ and we have rather leaned on their points of view that the lysis is causative of amylase liberation.

In the case of artificially disrupted cells.

Assuming that the synthesizing sites of amylase are located either on the cell 
surface (including the cell wall) or inside the cell, the enzyme would be released from the cell and get into the outer environment, if the cellular structures are disrupted. This would be the case also with the orange yellow pigment mentioned above. To confirm this postulation a series of experiments were followed. Cells were harvested by centrifuging at $10,000 \mathrm{rpm}$ for $15 \mathrm{~min}$. with a refrigerating centrifuge and were washed five times repeatedly with $1 / 15 \mathrm{M}$ phosphate buffer of $\mathrm{pH} 7.0$. Preliminarily the amylase activity of acetone dried cells was observed. When $20 \mathrm{~m} l$ acetone powder suspension (10 mg powder per $\mathrm{m} l$ dist. water) was incubated with $20 \mathrm{~m} l$ soluble starch solution $(2 \%)$ and $10 \mathrm{~m} l$ phosphate buffer solution of pH 7.0 at $30^{\circ}$, protecting with toluene, it gave $6.6 \mathrm{mg}$ reducing sugar per $1 \mathrm{ml}$ reaction mixture in $24 \mathrm{hrs}$. Next, the packed cells were mixed in buffer and disrupted completely by a $10 \mathrm{KC}$ Sonicator of Tominaga TI-100 (B) Model. In the control sample, cell suspension was prepared employing a flash mixer or a porcelain mortar, as the organism is slimy and the packed cells are not uniformly dispersed in the liquid with ease. Accordingly, in the control case, it is postulated that the cells are partially disrupted. It is obvious in Table 1 , that the saccharifying activity in the disrupted cell susnension

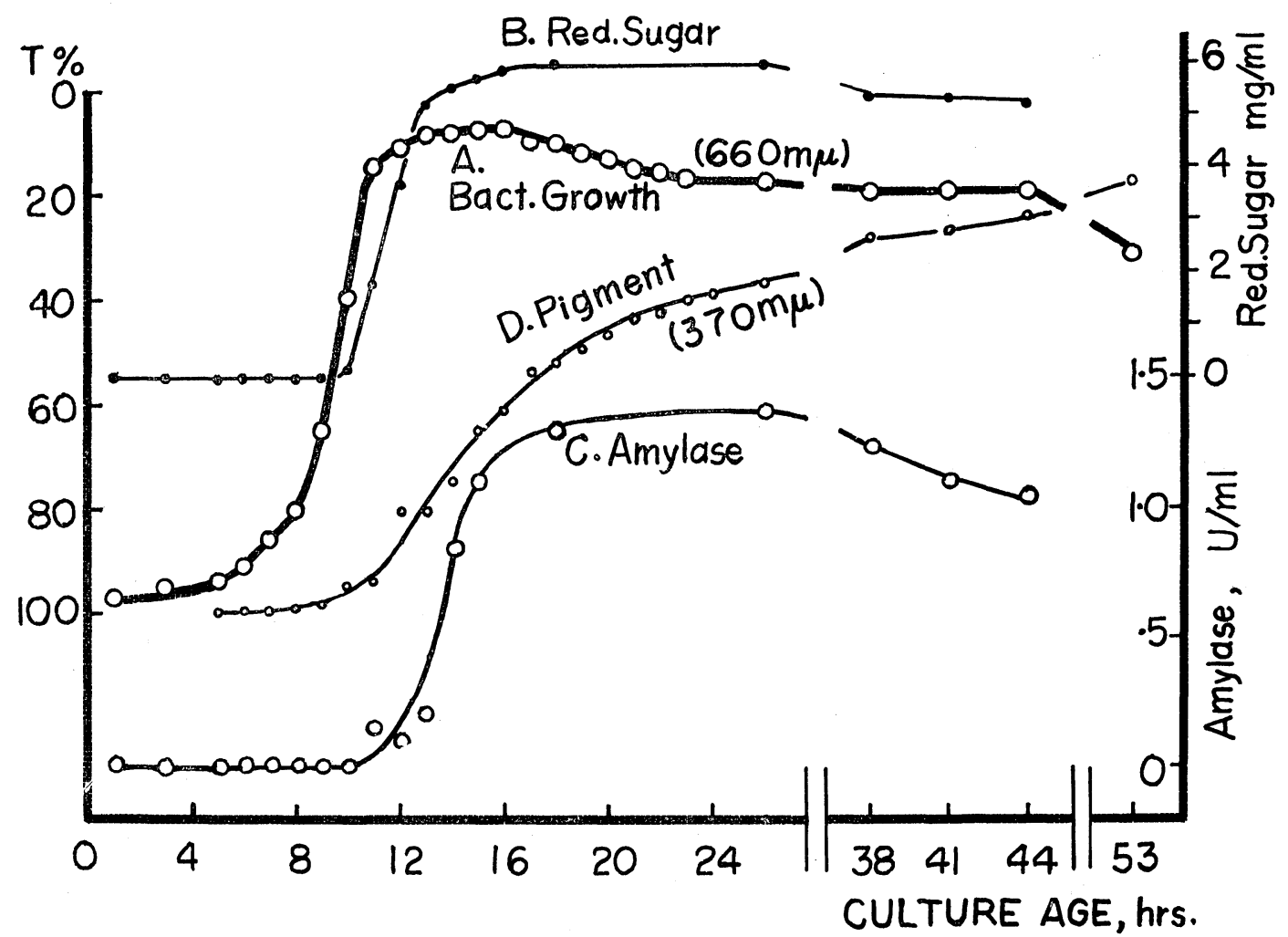

Fig. 1. The shifts of various factors in the course of culture.

Culture conditions are as in the text. Curve A, Bacterial growth, represented in $\mathrm{T} \%$ at $660 \mathrm{~m}_{l} ; \mathrm{B}-\mathrm{D}$, Factors in the culture supernatant; B, Reducing sugar, $\mathrm{mg} / \mathrm{ml}$; C, Saccharifying amylase; one "unit $/ \mathrm{ml}$ " is defined as such activity, that results in $10^{\circ} \mathrm{mg}$ reducing sugar from soluble starch incubated with $1 \mathrm{~m} l$ supernatant at $40^{\circ}$ for $30 \mathrm{~min}$; D, Pigment content respresented in $\mathrm{T} \%$ at $370 \mathrm{~m} \mu$. 
is higher than that in the control case. In Table 2, we see another effect of disruption. Aliquots of 10,16 and 53 hrs.' culture were treated with a sonicator, and the turbidities were compared with those of untreated samples at $660 \mathrm{~m} \mu$, respectively. With the supernatants of the just mentioned two groups of samples, the absorption at $370 \mathrm{~m} \mu$ was measured. We see in Table 2, in the case treated with a sonicator,

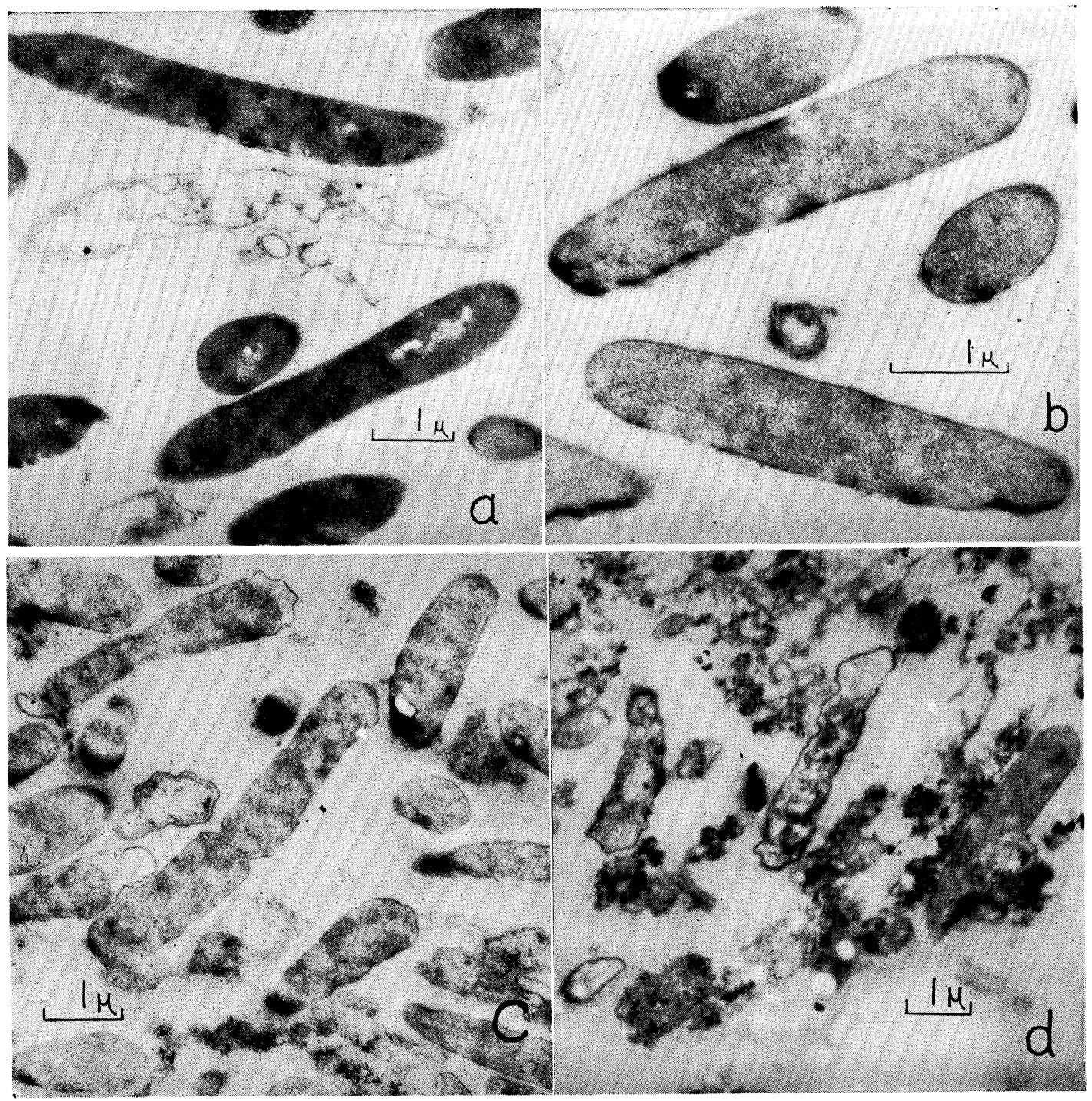

Fig. 2. Electron photomicrographs of the cells.

a, Whole cells and a lysed ghost cell in the earliest culture stage, i. e., in a small colony of scarcely visible size on the agar plate; b, c, d, Cells in shaking culture, showing the increase of morphological anomalies in the course of culture. Culture conditions are as in Fig. 1. b, in the $10 \mathrm{hrs}$ ' (log. phase) culture; c, population in the $12 \mathrm{hrs}$ (later log. phase) culture; d, population in the $15 \mathrm{hrs}$. (stationary phase) culture. 
Table 1. Reducing sugar produced in reaction mixture by totally or partially disrupted cells ( $\mu \mathrm{g}$ sugar/mg dry cell substances).

\begin{tabular}{l|c|c}
\hline Bacterial growth phase (culture age) & late log. $\left(13\right.$ hrs. $\left.^{*}\right)$ & stationary $(16$ hrs.) \\
\hline By cells totally disrupted & 2097 & 2825 \\
\hline $\begin{array}{l}\text { By cells partially disrupted (control } \\
\text { case) }\end{array}$ & 943 & 1134 \\
\hline Incubation period & 60 min. & overnight
\end{tabular}

Incubation, $30^{\circ}$; Reaction mixture, $2 \%$ soluble starch solution, $10 \mathrm{~m} l+$ disrupted cell suspension in phosphate buffer of $\mathrm{pH} 7.0,10 \mathrm{~m} l$.

* In this case, the bacterial growth was somewhat retarded.

Table 2. Effect of disruption of the cells in the culture.

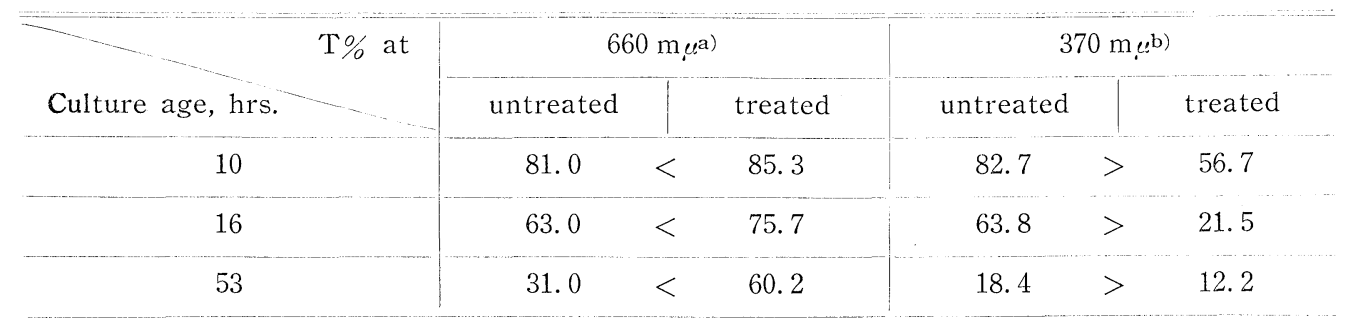

Culture conditions are as in Fig. 1. a) Culture, treated with a sonicator, $10 \mathrm{KC}, 3 \mathrm{~min}$. or untreated. Increase in $\mathrm{T} \%$ values represents the increase of lysis. b) Supernatant of culture mentioned in a). Decrease in $\mathrm{T} \%$ represents the increase of the orange yellow pigment. Further explanation in the text.

a distinct decrease in turbidity, with a marked increase in absorption at $370 \mathrm{~m} \mu$, i. e., the increase of orange yellow pigment, in each culture age, respectively.

From the facts presented in these two tables and described previously, we interpret the situation as follows: Saccharifying amylase and an orange yellow pigment are formed at some yet undefined site(s) of the cells in every culture age examined, and if the cells would lyse, whether naturally or not, they will be liberated from their sites and together get into the environment.

\section{Liberation of other factors}

Nomura ${ }^{1)}$ observed that the evident lysis occurred in Bacillus subtilis culture, in case the aeration by shaking was stopped. Similar phenomena were observed also in our case. Aliquots of 16 hrs'. (stationary phase) culture were aseptically poured into the test tubes for turbidimetry use up to the height of about $10 \mathrm{~cm}$, and were incubated in $20^{\circ}$ and $30^{\circ}$ without shaking. The turbidity of the samples decreased in the course of time, i. e., the lysis occurred in the culture. The lysis proceeded faster in $30^{\circ}$ than in $20^{\circ}$. An example case is shown in Fig. 3. Such facts mean that a certain lytic factor (or factors) should be formed in the course of cultivation. The nature and the site(s) of such a factor are now under investigation.

Besides the lysis of the cell in the course of culture, there occurs in culture medium a shift of the ultraviolet absorption spectrum. As shown in Fig. 4, the peak at $260 \mathrm{~m} \mu$ in culture supernatant is at first considerably high, but lowers afterwards with the culture age and completely diminishes in the stationary phase. We 


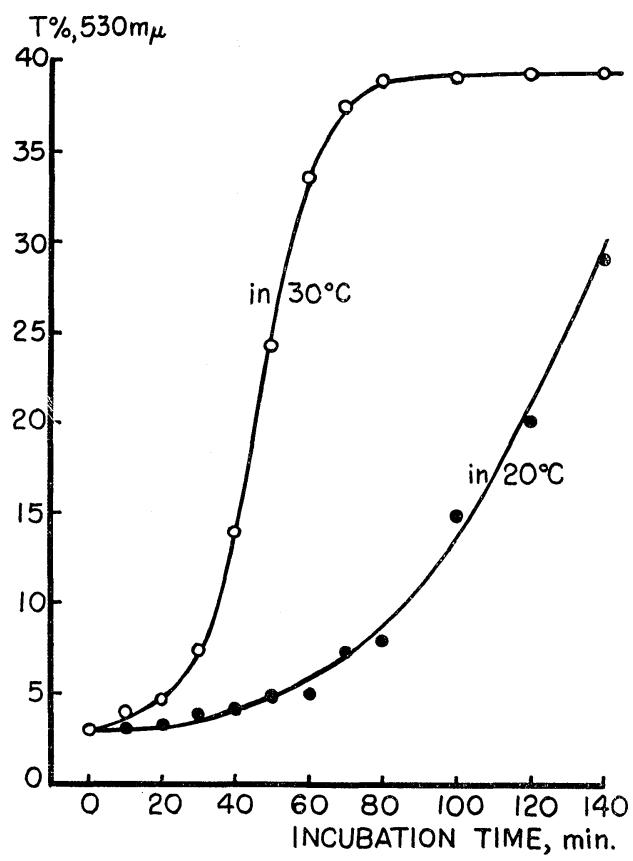

Fig. 3. Decrease of turbidity in the 16 hrs., (stationary phase) culture, when the aeration by shaking was stopped. Measured at $530 \mathrm{~m} u$. Further explanation in the text.

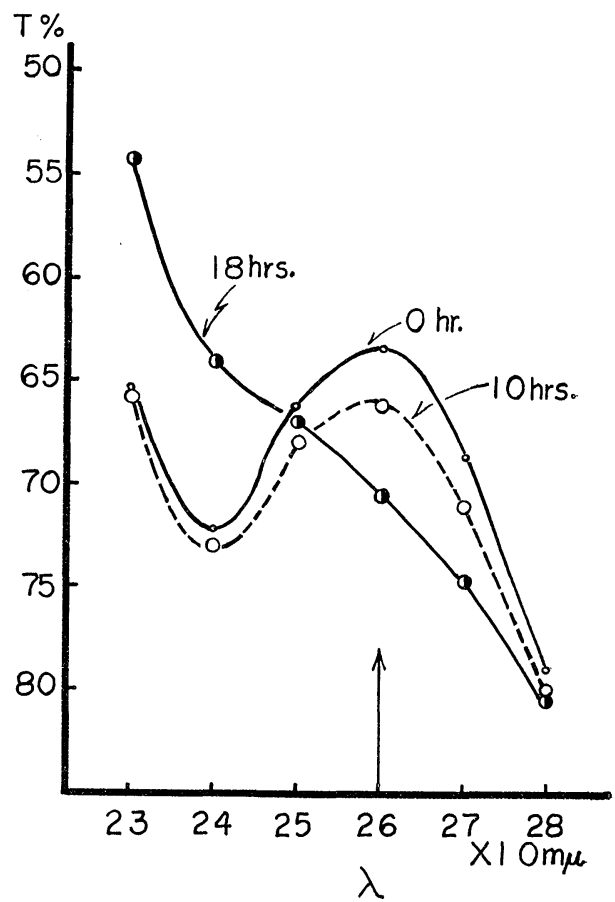

Fig. 4. Shift of UV-absorption spectra in the culture supernatant of various ages. Note the decrease of the peak at $260 \mathrm{~m} \mu$ in: the course of culture. Figures represent the culture ages. Culture conditions are as in Fig. 1. In spectrophotometry, the samples are diluted to one hundredth concentration with dist. water.

took this shift to be caused by consumption of some nucleic acid related substance(s). contained in yeast extract in the medium by bacteria as nutrient(s). Such a view would not be utterly wrong, but is not fully satisfying. If one mixes the sterilised, non-inoculated medium aseptically with supernatant (sterilised through Seitz's filter) of stationary phase culture and incubates the mixture for several hours at $30^{\circ}$ with gentle shaking, one will observe a marked change in the absorption spectra (curves A, B in Fig. 5). But such a shift does not occur, when the applied supernatant was. previously autoclaved (curves $\mathrm{C}$ and $\mathrm{D}$ ). After these facts, we reached a view, that the bacteria release some heat labile factor(s), which decompose or denature the 260 $\mathrm{m} \mu$ ultraviolet absorbing substances in the culture medium. The situation is similar to the case of exonuclease isolated by Nakai et al.6) and Okazaki et al. ${ }^{7)}$ in Bacillus subtilis culture fluid.

\section{Discussion}

As stated briefly in the opening paragraph, Pollock ${ }^{3)}$ assumed a critical attitude to Nomura's ${ }^{1,2)}$ opinion, that the $\alpha$-amylase liberation from Bacillus subtilis cells should 
be caused by autolysis, and stated: "It is, however, surprising that no activation is ever in fact observed, either when the cells are damaged or disrupted artificially". Yamamoto's criticism against Nomura's interpretation was based chiefly upon his view, that no $\alpha$-amylase should exist in the Bacillus subtilis cells. Our work was carried out regarding these comments and reached results to answer these two authors as follows.

The evident lysis of bacterial cells occurs in the course of culture, followed by the appearence of saccharifying activity in the medium. The saccharifying activity was confirmed definitely in the cells also, washed thoroughly five times repeatedly, in either fresh or acetone dried state. Miyamoto $^{8)}$ has observed formerly similar phenomena in Endomyces sp., strain IFO 0111, liberating saccharifying amylase. Such facts suggest that the lysis liberates the amylase in question bound in or on the cell. If this is the case, if one disrupts the cell, the bound enzyme, concomitantly with other cell components, should be released. This was demonstrated with the thoroughly washed cells of each culture age; i. e., the amylase activity was enhanced and the other cell components simultaneously increased in the system, in which the cells had been disrupted, compared with the control case. Therefore it would be sure that lysis, either natural or artificial, is the proximate cause of amylase release. Nomura $^{11}$ has already reported the $\alpha$-amylase formation in the protoplast of Bacillus subtilis. Oishi ${ }^{9)}$ also trapped $\alpha$-amylase in-

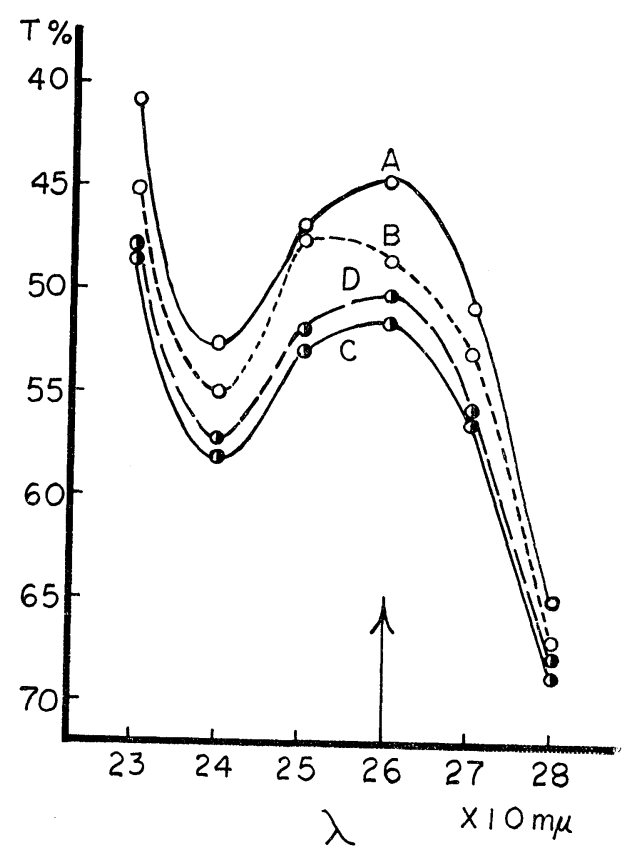

Fig. 5. Decrease of $260 \mathrm{~m} \mu$-absorbancy of the culture medium caused by a certain factor in the culture supernatant.

Reaction mixture, Non-inoculated medium, $10 \mathrm{~m} l+15$ hrs.' (stationary phase) culture sepernatant, $10 \mathrm{~m} l$. Both components are previously sterilized, i. e., the former autoclaved and the latter through bacterial filter. Incubation, $30^{\circ}, 6 \mathrm{hrs}$. with shaking. Curves A, C and B, D, Spectra before and after incubation, respectively. Curves $\mathrm{C}$ and D denote the spectra, when the applied culture supernatant is previously autoclaved. No decrease. In spectrophotometry, the samples are diluted to one hundredth concentration with dist. water. side the Bacillus subtilis cells, which were synthesizing and liberating the mentioned enzyme. Tonomura ${ }^{10,11)}$ and his colleagues determined by fluorescent antibody method the site of $\alpha$-amylase of Aspergillus oryzae in their cell wall. Takada ${ }^{12,13)}$, with his colleagues, demonstrated electron microscopically glandular-like systems of tubules and vesicles under the cell wall of Endomycopsis fibuliger, and suggested that these organelles represent a mechanism of amylase secretion. Such works confirm that the sites of amylase formation are located within the cell, including the cell wall. As Pollock ${ }^{3)}$ pointed out, if the cell wall would be a certain permeability barrier to the release of so-called exoenzymes, it would be assumed that the denaturation or destruction of the cell wall, and further the cell lysis should cause the amylase liberation. We consider this is also the case 
with saccharifying amylase in our bacteria.

But naturally we do not dare to conclude that the "lysis" is the causa causans in amylase liberation, though it may play a leading part in the logarithmic and stationary phases. On how inoculum cells meet and digest the starch molecule at the earliest stage of cultivation, nothing is yet revealed. But it is much suggestive that even in the earliest culture age, autolysis of the cells were demonstrated, though rarely, in the electron micrographs (Fig. 2, a).

\section{Acknowledgement}

We are grateful to Dr. K. Saga, Ehime Prefectural Institute of Hygiene and Dr. O. Ochi in our institute, under whose technical guidance the electron microscopical study was carried out. Thanks are due to the staff of Nippon Shiryô Kôgyô \& Co. They were so generous as to allow us to search for the amylase forming microbes in their starch pool.

\section{Summary}

The releasing mechanism of saccharifying amylase from bacterial cells was studied. The bacteria used were gram variable rods, belonging to Bacillus, highly active in amylase production, but not yet taxonomically defined. We named this strain tentatively " $\mathrm{AK}-3$ ".

1. In the course of cultivation the autolysis of the cells occurs, followed by the appearence of amylase in question. Concomitantly with the amylase, some cellular substances also appear in the environment, e. g., orange yellow pigment, a cell-lysing factor, a denaturant of $260 \mathrm{~m} \mu$ absorbing substance(s).

2. Disruption of the cells results in the increase of the amylase activity in the reaction mixture. This is also the case with the mentioned cellular substances.

3. From the facts described, we conclude that the amylase in this case are released from the cell chiefly by autolysis.

4. The mechanism of amylase liberation in the earliest stage of cultivation is not yet revealed.

\section{Reference}

1) Nomura, M., Hosoda, J., Yoshikawa, H., Nishimura, S., Maruo, B., and Akabori, S., More than twenty papers in 1955-1958. Works until 1957 are reviewed in: Symposia for the Society of Cellular Chemistry 6: 251 (Katsunuma, S., Ed., Maruzen, Tokyo, 1957). 2) Nomura, M., Hosoda, J., and Yoshikawa, H., J. Biochem. 45: 737 (1958). 3) Pollock, M. R., The Bacteria, Vol. 4, 121 (Gunsalus, I. C., and Stanier, R. Y., Ed., Academic Press, New York, 1962). 4) Yamamoto, T., Protein, Nucleic acid, Enzyme 10:690 (1965). 5) Miyamoto, Y., and Fukuoka, A., in press, Mem. Ehime Univ. Sect. II, Ser. B. 5 : (1966). 6) Nakai, M., Minami, Z., Yamazaki, T., and Tsugita, A., J. Biochem. $57: 96$ (1965). 7) Okazaki, R., Okazaki, T., and Sokabe, K., Biochem. Biophys. Res. Comm. $22: 611$ (1966). 8) Miyamoto, Y., unpublished experiments 9) Oishi, M., IV Symposium of Appl. Microbiol., Univ. Tokyo, 181 (1962). 10) Tonomura, K., Futai, F., and Tanabe, O., XV Symposia on Enzyme Chemistry, 153 (1963). 11) Tonomura, K. J., Agr. Chem. Soc. Japan 40 : R7 (1966). 12) Takada, H., Yagi, T., and Hiraoka, J., Protoplasma LIX : 494 (1964). 13) Hiraoka, J., and Takada, H., J. Biol. Osaka City Univ. 15: 83 (1964). 
摘

要

宮本義男・福岡明美・井川潚子： 溶菌にともなう糖化型アミラーゼ遊離

外酵素が細胞から遊離される機構については，まだ決定的な見解は得られていない，私たらは細菌の糖化 型アミラーゼの遊離と溶菌とが関連するか否かを考学ることとした．使用菌株はデンプン糖化能の高い一グ ラム不定 Bacillus である. その分類学的位置については別報するが，私たちは今とれを“AK-3 株”と 仮称するこの菌をデンプン酵母エキスから成る培地に振とう培養し，次の知見を得た。

対数期の終りに近い頃から培地中に糖化酧素活性が高まり, 静止期に入つて一定值に達する. 還元糖およ び特有の橙黄色色素もほぼ同様に推移する。アミラーゼ活性の高まりとともに, 培養中には溶菌像があらわ れ始めるが，溶菌は対数期の終りには著しく增加し，静止期にはほとえどすべての細胞が溶菌值前の様相を 示すにいたる。一方各培養令の細胞を音波破砕すると, 反応液の橙黄色調・糖化型アミラーゼ活性の増加す ることがみられる。

以上は, 自然的にせよ人工的にせよ，溶菌によって，このアミラーゼをはじめ細胞内容が培地中に解放さ れること, 少なくとも対数期以降におけるこの酵素の遊離は, 主として溶菌によるものと解せしめるもので

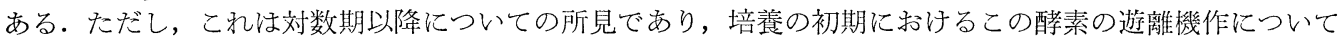
は別に究明されなければならない，一つの示唆として興味あることは，平板上にからうじて肉眼にみとめ得 る程度の微細な集落中にも溶菌像が認められることである。（愛媛大学交理学部生物学教室） 